\title{
A Phase li Dose Escalation Study of Intraarterial (Hepatic) Adult Human Bone Marrow Derived, Cultured, Pooled, Allogeneic Mesenchymal Stromal Cells (Stempeucel®) in Patients with Alcoholic Liver Cirrhosis
}

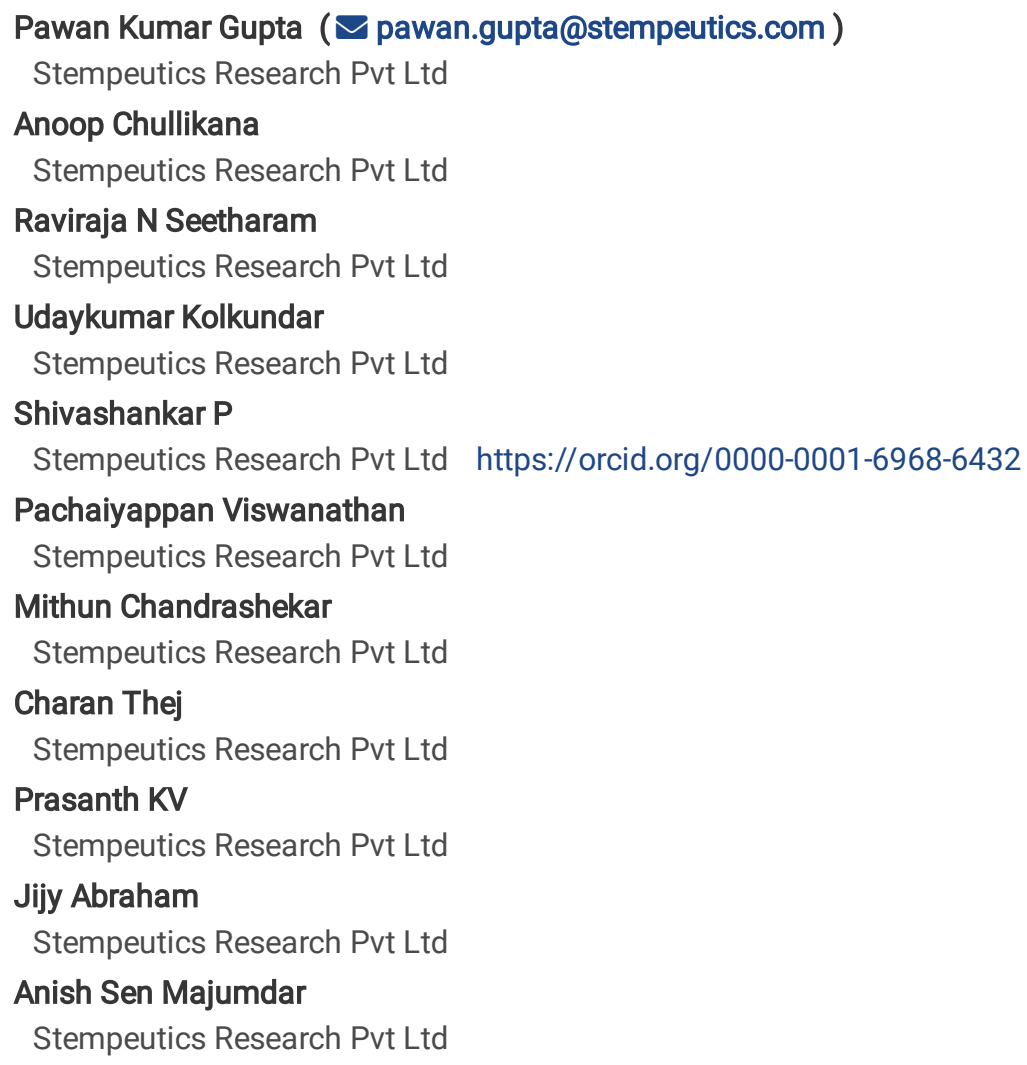

Research

Keywords: Mesenchymal Stromal Cells, Alcoholic Liver Cirrhosis, Child Pugh B and C, Model for End Stage Liver Disease score, Hepatic arterial administration (Seldinger technique)

Posted Date: February 4th, 2021

DOI: https://doi.org/10.21203/rs.3.rs-182673/v1

License: (c) (i) This work is licensed under a Creative Commons Attribution 4.0 International License. Read Full License 


\section{Abstract}

Background: Alcoholic liver cirrhosis is an end stage alcoholic liver disease with poor prognosis. The definitive treatment of alcoholic liver cirrhosis is orthotopic liver transplantation, which is expensive, requires long term immunosuppression and is limited by supply of organs. Being an unmet medical need, cell therapy is under investigation for alcoholic liver cirrhosis.

Aims: This study was designed primarily for assessing the safety and feasibility of administering stempeucel ${ }^{\circledR}$ through the hepatic artery in alcoholic liver cirrhosis and secondarily to assess possible efficacy and dose-response.

Methods: Forty patients with alcoholic cirrhosis (18-65 years/Child Pugh class B or C/Model for End-Stage Liver Disease score of minimum 10) were included in 4 groups: 2.5 million cells $/ \mathrm{kg}$ Body Weight (2.5M Cell) and respective control (2.5M Control); 5 million cells/kg Body Weight (5M Cell) and respective control (5M Control) with 10 patients in each group. Cell groups received stempeucel $\circledast$ administered via hepatic artery by catheterization through femoral artery (Seldinger technique) and Standard Protocol of Care. Control group received Standard Protocol of Care. Patients were followed up at 1 week, 1 month, 3 months and 6 months. Safety evaluations included clinical examination, Electrocardiogram and laboratory investigations. Efficacy evaluations included liver function test, Model for End-Stage Liver Disease score, Child Pugh score, Short Form-36 questionnaire, liver stiffness using Fibroscan (Transient Elastography), and liver volume using Computerized Tomography scan.

Results: stempeucel ${ }^{\circledR}$ injection was well tolerated. Common treatment emergent adverse events were in Gastrointestinal disorders, General disorders and administration site conditions and Infections and infestations. Most of the treatment emergent adverse events were unrelated / remotely related to stempeucel ${ }^{\circledR}$. Thirty serious adverse events occurred in 10 patients $(3$ in $2.5 \mathrm{M}$ Cell, 5 in $5 \mathrm{M}$ Cell and one each in control groups). Three patients died due to SAEs: Two in $2.5 \mathrm{M}$ and one in $5 \mathrm{M}$ Cell group, none were related to stempeucel ${ }^{\circledR}$. There was no significant difference in efficacy evaluations at 6 months versus baseline compared to control at both the dose levels of stempeucel ${ }^{\circledR}$. Statistically significant improvement was seen in $2.5 \mathrm{M}$ group compared to control group in Short Form-36 score: bodily pain, mental component summary, vitality and social functioning.

Conclusions: stempeucel ${ }^{\circledR}$ was safe, well tolerated and subjective improvement in few component scores of Short Form-36 was seen $2.5 \mathrm{M}$ cell group.

\section{Trial registration}

\section{Clinicaltrials.gov: NCT01591200}

\section{Clinical Trial Registry - India: CTRI/2009/091/000432}

\section{Background}

Alcoholic liver cirrhosis (ALC) is an end stage liver disease attributed to chronic alcohol intake. The prognosis of these patients is poor with nearly half of them dying after 1 year and $90 \%$ after 15 years (1). Currently available definitive treatment is orthotopic liver transplantation, which is prohibitively expensive and is limited by the shortage of organ supply. Adding to the complexity, there is a possible need for lifelong immunosuppression. Because of the unmet medical need of this condition, there has been extensive research into finding an effective treatment. Cell therapy is being evaluated in a host of conditions including liver diseases. Cells from different sources and different types of cells have been evaluated in ALC using different routes of administration. Bone marrow stem cells have a potential to differentiate into variety of cells in the body. Both hematopoietic and mesenchymal stem cells have been evaluated for ALC. Mesenchymal Stem Cells (MSC) have the advantages of relatively easy procurement from different sources, ex vivo expansion and ability to be used in an allogeneic recipient, thus potential to become an off-the-shelf cell therapy product.

Mesenchymal Stromal Cells (MSCs) have been known to differentiate to mesodermal (2), neuroectodermal and endodermal lineages (3). Importantly, MSC are shown to transdifferentiate to hepatocytes (4-7). In the presence of various factors like hepatocyte growth factor (HGF), epidermal growth factor, oncostatin $M$ and fibroblast growth factor, multipotent bone marrow cells can differentiate into hepatocytelike cells (3). Genomic plasticity is attributed to transdifferentiation of hepatocytes $(8,9)$. The mechanism of repair of liver damage by MSCs however, appears to be not limited to its transdifferentiation potential. MSCs secrete a host of factors that stimulate endogenous liver cells which participate in tissue repair $(10,11)$. Bone marrow mesenchymal stromal cells (BMMSC) secrete MMP-9 which degrades extracellular matrix through its antifibrotic effects (12). Induction of metalloproteinases by the MSCs enhance degradation of extracellular matrix thus reducing fibrosis $(12,13)$. Release of interleukin-10 (IL-10) and tumor necrosis factor (TNF) alpha decreases hepatic stellate cell proliferation and synthesis of type I collagen (14). Hepatic stellate cell apoptosis is induced by HGF and nerve growth factor secreted by 
MSC $(14,15)$. Fusion of donor BMMSC to recipient hepatocytes has also been cited as a reason for hepatic regeneration $(16,17)$. BMMSC reduce oxidative stress and inhibit apoptosis of hepatocytes (18). Vascular Endothelial Growth Factor secreted by MSCs induce angiogenesis and thus contribute to healing of target organ (19).

Zhang et al. (20) reported that the expression of human albumin, alfa fetoprotein (AFP), cytokeratin 18 and cytokeratin 19 were detected in the liver tissue of fibrotic and cirrhotic rats after MSC transplantation, suggesting that transplanted MSCs could migrate into the injured liver, where they could differentiate into hepatocyte-like cells. Furthermore, they also demonstrated that MSCs did not directly differentiate into functional hepatocytes; they first differentiated into epithelial cell-like cells and subsequently differentiated into hepatocyte-like cells. All the above findings indicated that MSCs could differentiate into hepatocyte-like cells through exposure to the liver fibrosis microenvironment both in vitro and in vivo.

Preclinical studies evaluating MSC in liver fibrosis are mostly in conducted in carbon tetrachloride induced liver fibrosis experimental model. Luo et al administered human BMMSC to rats through portal vein and found improvements in liver function and reduction in fibrosis associated with differentiation into hepatocyte-like cells (21). Tanimoto et al injected BMMSC through the tail vein into mice and found reduction in fibrosis, enhanced expression of MMP-9 and decreased expression of alpha smooth muscle actin (a-SMA), TNF alpha, transforming growth factor (TGF) beta (22).

In clinical setting, MSCs have been evaluated in various types of liver cirrhosis using different routes of administration. Jang et al administered 50 million autologous BMMSC through the hepatic artery in alcoholic cirrhosis and found improvements in Child Pugh score, decrease of TGF-beta1, collagen type 1 and a-SMA in addition to histological improvements (23). There are reports of studies involving BMMSC in chronic hepatitis C $(24,25)$, hepatitis B $(26)$ and Umbilical Cord Mesenchymal Stem Cells (UCMSC) in hepatitis B $(27,28)$ with successful outcomes. Most studies used a single dose level, had single arm and involved small sample size. We designed a dose finding study with the primary objective of evaluating the safety and feasibility of intraarterial (hepatic) administration of 3 dose levels (2.5, 5 and 7.5 million cells/ $\mathrm{kg}$ body weight) of stempeucel ${ }^{\circledR}$ in ALC.

"We present the following article in accordance with the CONSORT reporting checklist."

\section{Materials And Methods}

Study design

This trial was designed as a phase II, dose finding, parallel group, randomized, open label study. The protocol was approved by the Drugs Controller General of India (Indian FDA) and ethics committees of all 9 participating clinical trial sites. The study was conducted as per International Council for Harmonization Good Clinical Practice (ICH-GCP) guidelines, Principles of Declaration of Helsinki, Schedule Y of Drugs and Cosmetic Act, 1945, and Ethical guidelines for biomedical research on human participants, Indian Council of Medical Research, 2006. An independent data safety monitoring board (DSMB) was constituted to review the data of patients at predefined intervals and adhoc whenever required. Study was conducted in India. Informed consent was obtained from each patient before screening. The eligibility criteria are mentioned in Table 1. Patients were randomized to either cell or control group at each dose level ( 2.5 or 5 million cells $/ \mathrm{kg}$ ) as per predefined randomization code concealed from the investigators. At each dose level, 20 patients were randomized into 5 blocks with the block size of 4 patients. Study was registered in clinicaltrials.gov website (NCT01591200). 


\section{Inclusion Criteria}

1. Alcoholic cirrhotics between 18-65 years of age (both inclusive) (diagnosed by clinical, biochemical, sonographic, radiological [CT scan] or histological evidence of cirrhosis and portal hypertension).

2. Evidence of decompensated liver disease at screening (Child class B or C, Child-Pugh scores of $\geq 7$ and $<14$ ).

3. MELD scores of at least 10.

\section{Normal AFP Level (Normal AFP level to be considered as $\leq \mathbf{4 0} \mathrm{ng} / \mathrm{ml}$ )}

\section{5. $\mathrm{Hb}>10 \mathrm{gm} / \mathrm{dl}$.}

\section{Female of childbearing potential should use double contraception, of which one should be a barrier method during the course of the} study

\section{Signed informed consent.}

Exclusion Criteria

1. Patients listed for liver transplantation during screening

2. Presence of advanced hepatic encephalopathy Grades $3 \& 4$ (West Haven criteria for grading of hepatic encephalopathy) at the time of screening.

3. Active variceal bleed.

4. Refractory ascites.

5. Evidences of autoimmune liver disease: ANA (beyond 1:120 by immunoflourescence) or Anti-LKM positivity.

6. Platelet count $<50,000 / \mathrm{mm}^{3}$.

7. Serum Sodium $<129 \mathrm{mEq} / \mathrm{L}$.

8. Serum Creatinine $>1.2 \mathrm{mg} / \mathrm{dl}$.

9. Hepatocellular carcinoma or other malignancies

10. Active infection in the body.

11. Presence of severe underlying cardiac, pulmonary or renal disease.

12. Excessive alcohol (> $30 \mathrm{gm}$ of alcohol/day) use in the last 3 months before screening.

13. Positive HbSAg or antibodies to HIV or HCV.

14. Pregnancy or lactation.

15. Participation in any clinical trial within last 1 year

16. Patients unable to consent

17. Patients with hypersensitivity to the IMP and non-ionic radio contrast

\section{Production of stempeucel ${ }^{\circledR}$}

The bone marrow aspiration protocol was approved by the Institutional Ethics Committee. Healthy consenting voluntary donors in the age group 18-40 years, who were not Human Leucocyte Antigen matched to recipients were screened according to Indian Council of Medical Research guideline for healthy bone marrow donor screening. Sixty $\mathrm{ml}$ of bone marrow was aspirated from posterior superior iliac spine of both sides of each volunteer. It was diluted (1:1) with knockout Dulbecco's modified Eagle's medium (KO-DMEM; Gibco-Invitrogen, Grand island, New York, USA), and centrifuged at 1,800 (g) for 10 min to remove the anti-coagulant. Bone marrow Mononuclear Cells (BMMNCs) were separated by density gradient centrifugation $(1.077 \mathrm{~g} / \mathrm{ml})$ as described earlier (29). Plastic adherence was used to isolate BMMSCs from the donor BMMNC and cultured till passage 1. Donor master cell bank containing individual donor's BMMSCs was created and cryopreserved. Subsequently, a working cell bank (WCB) was prepared by combining MSCs from three individual donors and cryopreserved. The WCB was used for manufacturing stempeucel® and further expanding the pooled WCB for additional passages (US patent number 8956862 dated 02/17/2015). For the current clinical trial, pooled BMMSCs were cultured, harvested and characterized at passage 5 and cryopreserved in liquid nitrogen as the final product stempeucel ${ }^{\circledR}$, which was the investigational medicinal product (IMP). Specifications 
and release criteria of stempeucel ${ }^{\circledR}$ are the same as published by us earlier (30). Stempeucel $\circledast$ (200 million $\left.\pm 10 \%\right)$ was stored in $15 \mathrm{ml}$ of PLASMA-LYTE A (multiple electrolytes injection, type 1, United States Pharmacopeia) containing 5\% human serum albumin (Baxter Healthcare, California, USA) and 10\% dimethyl sulfoxide (Sigma - Aldrich, Irvine, United Kingdom) in a cryocyte bag (MacoPharma, Mouvaux, France). Stempeucel ${ }^{\circledR}$ was shipped to clinical trial sites in liquid nitrogen $\left(-185\right.$ to $\left.-196{ }^{\circ} \mathrm{C}\right)$ for each patient in the cell group.

Reconstitution of stempeucel® at clinical trial sites

Reconstitution of stempeuce ${ }^{\circledR}$ was done by a trained person independent of investigator's team. The procedure was done under a validated biosafety cabinet. Cryocyte bag containing stempeucel ${ }^{\circledR}$ was thawed in a water bath at $37{ }^{\circ} \mathrm{C}$. Cell suspension was diluted to 50 $\mathrm{ml}$ using PLASMA-LYTE A using $50 \mathrm{ml}$ centrifuge tube. Representative cell suspension sample was taken for performance of cell count. Based on cell count and body weight of the patient, final cell suspension was made in a total volume of not more than $50 \mathrm{ml}$ of PLASMALYTE A and transferred to a new cryocyte bag. The cryocyte bag was placed in a temperature controlled, validated transport box at $2-8{ }^{\circ} \mathrm{C}$ and shipped to the cath lab for intraarterial injection.

Intraarterial injection protocol

Before injecting stempeucel ${ }^{\circledR}$, patients were pre-medicated using 100 mg Inj. Hydrocortisone and 45.5 mg Inj. Pheniramine maleate (both administered intravenously). Seldinger technique was used for hepatic artery cannulation (31). Femoral artery was accessed using an introducer needle under local anesthesia. A soft tipped guide wire with a diameter of $0.038 \mathrm{~cm}$ was passed through the needle and the needle was removed. A dilator of a diameter of 6 French was passed over the guide wire. Dilator was removed and catheter (100-120 $\mathrm{cm}$ long with diameter of 5 French) was passed over wire and wire was removed. The catheter was guided into the coeliac axis. The catheter was then selectively negotiated into the hepatic artery. After accessing the hepatic artery (which is confirmed by injecting a non-ionic contrast agent), stempeucel ${ }^{\circledR}$ was injected in the artery at a rate of $1 \mathrm{ml} / \mathrm{min}$ using auto-injector.

Standard protocol of care was as per the investigator discretion and was given to patients both in stempeucel $\AA^{\circ}$ and control group. They included diuretics, antacids, multi vitamin preparations, laxatives, beta blockers, hepato-protectors, antidiarrheals, and systemic antibacterial medications. Control group did not receive any placebo injection due to invasive nature of administration.

Patient follow-up

All patients were observed for at least 24 hours after administration of stempeucel® before discharging from the hospital. Follow-up evaluations were done at 1 week, 1 month, 3 months and 6 months. Telephonic follow-up was done on 15th day for knowing the well-being of patients.

Study endpoints

Primary endpoint was safety and tolerability, assessed by occurrence and type of treatment emergent adverse events (TEAEs) (onset on or after the IMP administration visit [for cell group] and randomization visit [for control group]), electrocardiogram parameters, hematological and biochemical values, physical examination and vital signs. Secondary endpoints included assessment of efficacy by liver function tests (LFT), Model for End-Stage Liver Disease (MELD) and Child Pugh score, Quality of life as per Short Form-36 (SF-36) questionnaire, liver stiffness measured by Fibroscan and volume of liver measured by Computerized Tomography (CT) scan.

Data collection

Electronic case record form was used for data collection. Data was verified with source notes by third party monitors independent of investigators.

\section{Data Safety Monitoring Board}

An independent DSMB was constituted comprising of drug safety physicians, pharmacovigilance expert and gastroenterologist. The DSMB first met during protocol finalization. Second meeting was held to review the 1 week follow-up data of 20 patients in the 2.5 million cells/kg dose level (both cell and control group). Third meeting was held to review the data of 20 patients in the 5 million cells/kg dose level (both cell and control group) along with the cumulative data of all patients in the 2.5 million cells/kg body weight dose group. Final meeting was planned to review of safety data of first five patients in the cell group of 7.5 million cells/ $\mathrm{kg}$, along with other cumulative data before dosing remaining patients at this dose level.

Statistical analysis

Page 5/22 
SAS package (SAS Institute Inc, USA, version 9.2) was used for statistical analysis. Data are presented as mean \pm SD. TEAEs are summarized descriptively by total number of AEs in each group by system organ class (SOC). Normality of continuous data was tested using Kolmogorov-Smirnov test. Efficacy data was analyzed using Analysis of Covariance or Nonparametric Wilcoxon Rank Sum test as appropriate. $\mathrm{P}<0.05$ was considered statistically significant. Efficacy data are presented for modified intention to treat population, which represents the patients who had at least one post baseline efficacy data point.

\section{Results}

Of the 69 patients screened, 40 were enrolled in the study. At each dose level, 20 patients were randomized to either cell group or control group. The CONSORT diagram (Fig. 1) shows the number of patients screened, enrolled to each group and completing the 6 months followup.

\section{Patient characteristics}

The demographics and baseline characteristics of the patients are given in Table 2. It is seen that the groups are matched in terms of baseline characteristics.

Table 2

Demography and baseline characteristics

\begin{tabular}{|c|c|c|c|c|}
\hline \multirow[b]{2}{*}{ Parameter } & \multicolumn{2}{|c|}{2.5 Million cells/kg } & \multicolumn{2}{|l|}{5 Million cells $/ \mathrm{kg}$} \\
\hline & Cell $(n=10)$ & Control $(n=10)$ & Cell $(n=10)$ & Control $(n=10)$ \\
\hline Male & 10 & 10 & 10 & 10 \\
\hline Age (years) & $45.20 \pm 8.93$ & $44.90 \pm 5.63$ & $50.90 \pm 6.01$ & $48.20 \pm 8.57$ \\
\hline Height (cm) & $167.90 \pm 7.87$ & $167.27 \pm 3.80$ & $164.62 \pm 7.55$ & $165.02 \pm 5.76$ \\
\hline Weight (kg) & $64.47 \pm 9.85$ & $71.64 \pm 18.16$ & $65.13 \pm 13.46$ & $59.47 \pm 13.14$ \\
\hline Total Bilirubin (mg/dL) & $3.15 \pm 1.12$ & $2.84 \pm 1.26$ & $2.97 \pm 2.35$ & $2.74 \pm 1.73$ \\
\hline Direct Bilirubin (mg/dL) & $1.31 \pm 0.73$ & $1.18 \pm 0.60$ & $1.63 \pm 1.65$ & $1.59 \pm 1.42$ \\
\hline Total Protiens (g/dL) & $6.49 \pm 0.40$ & $6.99 \pm 0.70$ & $7.66 \pm 0.52$ & $7.40 \pm 0.59$ \\
\hline Serum Albumin (g/dL) & $2.74 \pm 0.49$ & $2.55 \pm 0.303$ & $2.70 \pm 0.49$ & $2.62 \pm 0.60$ \\
\hline Serum Globulin (g/dL) & $3.76 \pm 0.54$ & $4.44 \pm 0.79$ & $4.96 \pm 0.49$ & $4.78 \pm 0.70$ \\
\hline A:G ratio & $0.74 \pm 0.26$ & $0.59 \pm 0.12$ & $0.55 \pm 0.13$ & $0.58 \pm 0.22$ \\
\hline Alanine Aminotransferase (ALT) (U/L) & $43.90 \pm 10.96$ & $41.90 \pm 7.25$ & $38.80 \pm 10.37$ & $46.90 \pm 15.48$ \\
\hline Aspartate & $68.10 \pm 29.57$ & $55.20 \pm 20.06$ & $59.50 \pm 24.09$ & $63.40 \pm 35.74$ \\
\hline \multicolumn{5}{|l|}{ Aminotransferase (AST) (U/L) } \\
\hline Alkaline Phosphatase (ALP) (U/L) & $172.50 \pm 43.22$ & $216.70 \pm 129.04$ & $199.90 \pm 143.40$ & $222.80 \pm 113.69$ \\
\hline GGT (U/L) & $78.90 \pm 66.18$ & $118.80 \pm 159.37$ & $109.90 \pm 99.65$ & $124.10 \pm 166.17$ \\
\hline Liver Volume (cm3) & $1273.2 \pm 424.24$ & $1284.7 \pm 376.07$ & $1038.8 \pm 364.10$ & $1262.1 \pm 486.15$ \\
\hline MELD Score & $17.00 \pm 2.00$ & $18.00 \pm 6.51$ & $16.90 \pm 4.15$ & 15.00 \\
\hline Child-Pugh Score & $9.3 \pm 1.25$ & $9.2 \pm 1.48$ & $8.8 \pm 1.62$ & $9.1 \pm 1.45$ \\
\hline $\mathrm{CAP}(\mathrm{dB} / \mathrm{m})$ - Fibroscan & $210.1 \pm 60.96$ & $247.8 \pm 48.38$ & $213.8 \pm 35.69$ & $226.0 \pm 40.14$ \\
\hline $\mathrm{E}(\mathrm{kPa})$ - Fibroscan & $61.2 \pm 18.53$ & $61.2 \pm 15.32$ & $55.3 \pm 20.84$ & $36.8 \pm 33.49$ \\
\hline Physical component summary (SF-36) & $40.36 \pm 7.82$ & $38.20 \pm 5.73$ & $39.45 \pm 10.06$ & $42.77 \pm 4.48$ \\
\hline Mental component summary (SF-36) & $43.91 \pm 8.38$ & $46.93 \pm 7.64$ & $40.05 \pm 10.58$ & $42.73 \pm 5.01$ \\
\hline Data are expressed as Mean \pm SD & & & & \\
\hline
\end{tabular}


Most patients tolerated the intraarterial injection of stempeucel ${ }^{\circledR}$ without any safety issues except one patient, who developed dissection of hepatic artery during catheterization. Procedure was aborted immediately and stempeucel $\circledast$ was not administered. This patient was observed for 24 hours before discharging the next day without further complications. However, the patient died due to complications associated with liver cirrhosis 1 month later.

TEAEs during the follow-up period are summarized in Table 3. Common TEAEs were in the SOC Gastrointestinal disorders, General disorders and administration site conditions, and Infections and infestations. Most of the TEAEs were unrelated / remotely related to the IMP. Electrocardiogram parameters, hematological and biochemical values, physical examination and vital signs did not reveal any significant abnormalities compared to baseline (data not presented).

Table 3

Summary of treatment emergent adverse events

\begin{tabular}{|c|c|c|c|c|}
\hline \multirow[b]{2}{*}{ System Organ Class (SOC) } & \multicolumn{2}{|l|}{2.5 Million cells/kg } & \multicolumn{2}{|l|}{5 Million cells/kg } \\
\hline & Cell & Control & Cell & Control \\
\hline & $(N=10)$ & $(\mathrm{N}=10)$ & $(\mathrm{N}=10)$ & $(\mathrm{N}=10)$ \\
\hline & Events (Patients) & Events (Patients) & Events (Patients) & Events (Patients) \\
\hline Treatment Emergent Adverse Events & $43(5)$ & $24(6)$ & $32(6)$ & $13(6)$ \\
\hline Blood and lymphatic system disorders & $1(1)$ & 0 & $1(1)$ & 0 \\
\hline Endocrine disorders & $1(1)$ & 0 & 0 & 0 \\
\hline Gastrointestinal disorders & $17(4)$ & $9(4)$ & $10(4)$ & $3(3)$ \\
\hline General disorders and administration site conditions & $9(4)$ & $5(2)$ & $3(3)$ & $5(2)$ \\
\hline Hepatobiliary disorders & 0 & 0 & $1(1)$ & 0 \\
\hline Infections and infestations & $4(2)$ & $2(2)$ & $7(4)$ & $2(2)$ \\
\hline Investigations & $2(2)$ & $3(1)$ & 0 & 0 \\
\hline Metabolism and nutrition disorders & $1(1)$ & $2(2)$ & 0 & 0 \\
\hline Musculoskeletal and connective tissue disorders & $3(2)$ & $1(1)$ & 0 & 0 \\
\hline Nervous system disorders & $3(3)$ & 0 & $3(2)$ & $2(1)$ \\
\hline Psychiatric disorders & 0 & $1(1)$ & 0 & 0 \\
\hline Renal and urinary disorders & $1(1)$ & 0 & $2(2)$ & 0 \\
\hline Reproductive system and breast disorders & 0 & $1(1)$ & 0 & 0 \\
\hline Respiratory, thoracic and mediastinal disorders & $1(1)$ & $1(1)$ & $4(2)$ & $1(1)$ \\
\hline Skin and subcutaneous tissue disorders & 0 & $1(1)$ & 0 & 0 \\
\hline Vascular disorders & 0 & 0 & $1(1)$ & 0 \\
\hline
\end{tabular}

Thirty Serious adverse events (SAE) occurred in 10 patients (3 in $2.5 \mathrm{M}$ Cell, 5 in $5 \mathrm{M}$ Cell and one patient each in control groups) in the study. Three patients died due to SAEs: Two in 2.5M Cell group (both due to hepatic encephalopathy and associated complications) and one in $5 \mathrm{M}$ Cell group (due to bilateral bronchopneumonia with sepsis with renal failure), none of which were related to stempeucel ${ }^{\circledR}$ as per the investigators.

\section{DSMB recommendation}

Upon review of data during second meeting, the DSMB opined that there was no safety concerns noted and recommended that the next higher dose of 5 million cells/kg body weight of the IMP may be administered as per the protocol. In the third meeting, the DSMB observed that the patients in the cell groups of the study, and more so who received 5 million cells/kg body weight have experienced more SAEs in 
SOC of infections than those in the control group. The DSMB recommended that the study be stopped with no further IMP administration; however the monitoring of the patients had to be continued as per protocol. Cause of infection was not attributed to the IMP by the DSMB. As per the investigators, infections were not related to the IMP except fever in one patient (which occurred after 2 weeks following injection of 2.5 million cells/ $\mathrm{kg}$ body weight, labeled as possibly related) and bacteremia in another patient (which occurred after 4 months following 5 million cells/kg body weight, labeled probably related). Ethics committees and the expert committee under DCGI opined that none of the SAEs were related to the IMP.

Efficacy results

Data of LFT, Child Pugh score, MELD score and SF-36 are presented in Figs. 2 to 6 . There were no clinical improvements in any group and no differences between the groups in LFT, Child Pugh and MELD scores. Analysis of SF-36 parameter showed that there was a statistically significant improvement in $2.5 \mathrm{M}$ cell group compared to $2.5 \mathrm{M}$ control group at 6 months when compared to baseline in the following parameters: bodily pain ( $44.03 \pm 11.08$ to $52.96 \pm 8.58$ in $2.5 \mathrm{M}$ cell vs. $43.29 \pm 6.35$ to $44.51 \pm 7.04$ in $2.5 \mathrm{M}$ control [p $=0.031])$, mental component summary ( $43.91 \pm 8.38$ to $49.31 \pm 8.20$ in $2.5 \mathrm{M}$ cell vs. $47.36 \pm 7.97$ to $39.35 \pm 7.65$ [p $=0.035])$, vitality $(47.72 \pm 8.86$ to $57.29 \pm$ 8.98 in $2.5 \mathrm{M}$ cell vs. $49.66 \pm 3.41$ to $48.97 \pm 5.41$ in $2.5 \mathrm{M}$ control [p=0.0329]) and social functioning (44.31 \pm 5.78 to $46.85 \pm 11.134$ in $2.5 \mathrm{M}$ cell vs. $44.73 \pm 10.12$ to $37.46 \pm 6.17$ in $2.5 \mathrm{M}$ control $[p=0.0356]$ ). Liver stiffness measured by Fibroscan (Table 4 ) and liver volume measured by CT scan (Table 5) did not show any difference between cell and control groups at both the dose levels.

Table 4

Fibroscan

\begin{tabular}{|lllll|}
\hline \multicolumn{4}{l}{2.5 million cells/kg } & \multicolumn{2}{l|}{$\mathbf{5}$ million cells/kg } \\
\hline Parameters & Cell & Control & Cell & Control \\
& $(\mathrm{n}=10)$ & $(\mathrm{n}=9)$ & $(\mathrm{n}=9)$ & $(\mathrm{n}=9)$ \\
\hline CAP $(\mathrm{dB} / \mathrm{m})$ Baseline & $210.1 \pm 60.96$ & $256.9 \pm 44.23$ & $216.3 \pm 37.32$ & $226.3 \pm 43.96$ \\
\hline CAP $(\mathrm{dB} / \mathrm{m})$ 6 Months & $219.2 \pm 60.74$ & $208.3 \pm 19.75$ & $228.6 \pm 63.93$ & $195.0 \pm 40.26$ \\
\hline P Value & & 0.3618 & & 0.1629 \\
\hline E $(\mathrm{kPa})$ Baseline & $61.2 \pm 18.53$ & $61.5 \pm 16.24$ & $56.4 \pm 21.99$ & $40.2 \pm 34.03$ \\
\hline E $(\mathrm{kPa})$ 6 Months & $57.0 \pm 18.28$ & $51.1 \pm 22.46$ & $48.6 \pm 21.67$ & $38.0 \pm 21.50$ \\
\hline P Value & & 0.1393 & & $>0.9999$ \\
\hline Values represent mean \pm SD & & & \\
\hline
\end{tabular}

Table 5

Liver volume measured by Computed Tomography Scan

\begin{tabular}{|lllll|}
\hline & 2.5 Million cells/kg & 5 Million cells/kg \\
\hline Visit/ Parameters & Cell & Control & Cell & Control \\
& $(\mathrm{n}=10)$ & $(\mathrm{n}=9)$ & $(\mathrm{n}=9)$ & $(\mathrm{n}=9)$ \\
\hline Liver Volume $(\mathrm{cm} 3)$ (Baseline) & $1273.2 \pm 424.24$ & $1263.6 \pm 392.53$ & $1074.0 \pm 367.69$ & $1290.3 \pm 506.87$ \\
\hline Liver Volume $(\mathrm{cm} 3)$ (6 Months) & $1077.2 \pm 448.68$ & $1143.3 \pm 243.89$ & $996.1 \pm 292.81$ & $862.7 \pm 286.30$ \\
\hline P Value & & 0.81 & & 0.02 \\
\hline Values represent Mean \pm SD. & & & & \\
\hline
\end{tabular}

\section{Discussion}

To our knowledge, this is the first dose finding study using allogeneic BMMSC in ALC. Study has shown that it is feasible to administer stempeucel ${ }^{\circledR}$ at a dose of 2.5 million \& 5 million cells $/ \mathrm{kg}$ body weight through the hepatic artery in ALC. The procedure was reasonably tolerated well in majority of patients though one patient in the 5 million cells/kg dose group developed hepatic artery dissection during 
catheterization. There were higher incidents of infections in patients who received 5 million cells $/ \mathrm{kg}$ body weight compared to control group even though not all were attributed to stempeucel $\circledast$ by the investigators.

Hepatic artery catheterization has been in practice since 1960 s for administering anticancer chemotherapy $(32,33)$ and hepatic arterial dissection is a known complication of this procedure. In a report by Habbe et al, six incidents of hepatic artery dissections were observed in 100 attempted hepatic arterial catheter placements for administering chemotherapy (34). In another study of chemotherapy for hepatic malignancy, there was one incidence of hepatic artery dissection out of 28 patients (35). Similarly, intraarterial chemotherapy resulted in one case of hepatic artery dissection out of 30 patients (36). In a phase 1 study of bone marrow mononuclear therapy in cirrhosis in 8 patients, there was one incidence of hepatic artery dissection (37). Thus, the incidence of this complication in our study (one in 20 patients) is comparable to that reported in studies involving hepatic artery catheterization including those intended for stem cell delivery.

The DSMB opined that there is increased incidence of infection in the cell group compared to that of control. Theoretically, MSC can lead to enhanced susceptibility to infection through immunomodulatory function, particularly in patients with liver cirrhosis due to immunosuppression. It is possible that the increased rate of infection in this study was also because of preexisting immunosuppression due to cirrhosis in these patients. Infection and its complications were seen in similar studies involving administration of stem cells in liver cirrhosis. In a study by Sharma et al, one patient died on the 88th day post CD34 + cell transplantation due to development of sepsis and hepatorenal syndrome (38). In a case report by Gasbarrini et al, infusion of CD34 + resulted in fatal outcome due to multiorgan failure secondary to bacterial infection (39). Autologous bone marrow cell infusion in patients with liver cirrhosis resulted in fever in all recipients in a study by Terai $S$ et al (40). Two patients developed self-limiting fever within 2-6 hours after UCMSC administration in acute-on-chronic liver failure patients (28). Hence it appears that infections and its complications are a common place in interventions involving cell therapy in morbid liver conditions.

Infections following stem cell administration have been seen in non-cirrhotic conditions also. In a phase I study using autologous BMMSC for therapy of allograft rejection following renal transplantation, 3 out of 6 patients developed opportunistic viral infection (41). This has been speculated to be due to the immunosuppressive effects of MSC (42). In Graft versus host disease patients, MSC therapy has raised concerns over infections as a complication (43). However, a meta-analysis of MSC studies showed that there was no difference between MSC and control groups in terms of occurrence of infection (44). The same report revealed a significant increase in transient fever in MSC group compared to control probably due to acute inflammatory reactions to particular MSC preparations.

Paradoxically, BMMSCs are thought to be protective against infectious diseases through direct effects on pathogens or indirect effect on the host. While they reduce proinflammatory cytokine and chemokine induction and reduce the migration of proinflammatory cells into sites of injury in the host, they also exert antimicrobial effect on the infectious agents (45). Mechanism of antimicrobial effects include indoleamine 2,3-dioxygenase expression induced by inflammatory cytokines (46) and secretion of cathelicidin LL-37 antimicrobial peptide (47). Antifungal effect has also been demonstrated by IL-17 producing subset of MSC (48). Beneficial role of MSC has also been discussed in tuberculosis, through immunomodulatory functions favorable to the host and down regulation of host susceptibility to infection (49). Sepsis, which is a deranged response of host immune mechanism to microbial invasion, results in organs damage. MSC has been considered a suitable agent to be tested for sepsis because of its antibacterial, immunomodulatory effect, antiapoptosis and regenerative response (50). Extensive preclinical studies have demonstrated efficacy of MSC in animal models of sepsis $(51,52)$. One clinical trial has also been initiated using MSC in septic shock (53). Arango-Rodriguez has reviewed the mechanisms through which MSCs can facilitate infection in the recipient as well as literature suggesting that MSC may reduce infection (54). Conflicting opinions about role of MSC in infection are probably because of the heterogenicity in MSC with respect to its source, dose, route of administration and the disease condition in which it is administered.

Cell therapy can be administered to liver cirrhosis patients through different routes: peripheral vein, portal vein, spleen and hepatic artery. Intravenous delivery has been commonly used for administration of cells in liver cirrhosis patients. Portal vein catheterization has technical challenges due to ascites in these patients and additional risk of portal vein thrombosis and subsequent variceal bleed. Intrasplenic route has been used by few studies for cell administration in liver cirrhosis $(25,55)$. Hepatic artery catheterization was chosen in our study, owing to higher proportion of cells possibly lodging in liver. Other than dissection, the potential complication of this route of delivery is worsening of liver function due to embolization. Deterioration of liver function was not seen following cell administration in this study, ruling out liver damage due to cell embolization. There were no other immediate complications directly attributed to stempeucel $\AA^{\text {. Study by }}$ Mohamadnejad et al was prematurely stopped because patients developed complications renal failure and radio-contrast nephropathy, and concluded that injection of CD34 + cells through hepatic artery was probably unsafe (56). However, later studies involving CD34 + cells infusion through hepatic artery did not show such safety issues with administration of CD3 + cells through hepatic $(38,57-59)$. 
This study was designed primarily for assessing the safety and feasibility of administering stempeucel ${ }^{\circledR}$ through the hepatic artery in ALC. As a secondary objective, we also explored possible efficacy and dose-response. Efficacy was seen only in quality of life of patients who received 2.5 million cells/kg dose of stempeucel ${ }^{\circledR}$ compared to control as seen in few mental component scores of SF-36. This may be partially due to open label nature of the study. SF-36 improvement was seen in a study by Salama et al following haematopoietic stem cells therapy in end-stage liver disease patients (60). Quality of life improvement associated with clinical improvement was seen in a study by Kim et al evaluating autologous bone marrow infusion in advanced liver cirrhosis (61). The lack of obvious clinical efficacy seen in this study may be attributed to three reasons: Firstly, the eligibility criteria included patients in the higher severity of liver cirrhosis (Child Pugh class B and C). It is possible that these patients were already in advanced stage of the disease and not amenable for cell therapy. Probably cell therapy has to be attempted at an early stage of disease like alcoholic hepatitis, rather than at a late stage when cirrhosis has already set in. The alcoholic hepatitis stage may help better homing of cells because of the local inflammation. In the advanced stage, it may be difficult for the cells to home to the site of action since there is no active inflammation. Secondly, the starting dose selected for this study ( 2.5 million cells/kg body weight) might be in the upper end of therapeutic range; higher doses potentially leading to deleterious effects. Lastly, in-spite of strongly conveying the need of alcohol abstinence, some patients might have consumed alcohol during the study, which might have negatively affected the clinical outcome. While most pilot studies involving stem cells in liver cirrhosis had successful outcomes, few studies had negative results. Mohamadnejad, who pioneered the MSC administration in liver cirrhosis with several successful pilot studies, found no benefit of intravenous BMMSC administration compared to placebo in a randomized trial (62). Recently, a double blind study by the same group using BMMNC administered through portal vein in decompensated cirrhosis showed overall no benefit albeit a transient benefit at 3 months (63).

Evidence of efficacy of stem cells requires demonstration of tissue regeneration in addition to proving clinical benefit. Tucker et al recommended a triad of outcome measures for cell therapy trials: demonstration of mechanism of action in terms of cellular response, clinical evidence of improvement and structural benefit (64). This translates to clinical and biochemical improvements in liver cirrhosis, which are easier to demonstrate and structural changes through histopathology of liver tissue, which is a complex procedure. Liver biopsy is challenging especially in cirrhotic patients though several studies have included this procedure. Terai et al has shown that there was improvement in serum albumin, total protein, AFP and proliferating cell nuclear antigen in liver biopsy after 4 weeks of autologous BMMNC infusion therapy (40). Zhang et al showed improvement in ascites, liver function, MELD score in addition to decrease in liver fibrosis markers (27). Kim et al have demonstrated increasing activation of hepatic progenitor cell compartment, hepatic progenitor cell differentiation, and improvement in Child Pugh scores (61). Interestingly, 80\% patients showed increase in liver volume as per Magnetic Resonance Imaging. Jang et al have seen histological improvement in 6 out of 11 patients who received BMSC through the hepatic artery for ALC (23). Enhanced angiogenesis was seen in follow-up liver biopsy specimens after boost infusions of mobilized peripheral blood stem cells in decompensated alcoholic cirrhosis in a study by Yannaki et al (65). In the present study, we did not conduct liver biopsy at 6 months follow-up. It is debated that small tissue sample may not be adequate representation of liver pathology and may be subject to sampling error and intra-observer variation $(66,67)$. Hence, Fibroscan (Transient Elastography) which is a non-invasive technique of assessment of liver stiffness was employed in this study. This method has been validated for diagnosis of liver cirrhosis (68) and was found to be reproducible in patients with chronic liver disease (69). Hence Fibroscan is considered to be an option instead of liver biopsy (70). In this study, there was no change from baseline in Continuous Attenuation Parameter and liver stiffness indicating there is no worsening or improvement in liver fibrosis. To our knowledge, Fibroscan has not been used in published studies involving cell therapy in liver cirrhosis, though the REALISTIC study protocol evaluating CD133 + cells incorporates this technique (71).

Several approaches have been evaluated for improving efficacy of cell therapy in liver cirrhosis. Animal studies have shown that pretreatment of MSC with injured liver cells has improved the ability of MSC for homing and hepatic differentiation (72). Amer et al differentiated the MSC towards hepatocytes by pretreating them with HGF before infusion via intrahepatic or intrasplenic routes in patients with end-stage liver cell failure due to chronic hepatitis $\mathrm{C}$ and found improvement in cell treated group (55). However, El-Ansary et al found no difference in efficacy between MSCs differentiated to hepatocytes and undifferentiated MSCs in hepatitis C virus induced liver cirrhosis (24). Salama et al administered granulocyte-colony stimulating factor (G-CSF) daily for 5 days before administering MSC through the peripheral vein (73). Recently, co-administration of MSC with PPAR gamma agonists has been tried with encouraging results (74). Repeat injection has been tried in cell therapy studies. Jang et al administered autologous BMMSC at baseline, and again after 4 weeks and found that histological improvement was seen in 6 out of 11 patients and Child Pugh score improved in ten patients (23). In a study by Zekri et al, liver cirrhosis patients were randomized to receive one session of autologous haematopoietic stem cells followed by MSC, two sessions of similar treatment separated by 4 months or control (75). It was observed that while one session group showed improvement in serum albumin, bilirubin and INR values till 6 months, two session group sustained improvement till 12 months. Zhang et al have tried UCMSC administration thrice, using peripheral vein and showed clinical improvements and MELD scores (27). REALISTIC study aims to evaluate improvement in disease severity using GCSF alone or G-CSF followed by repeated infusion of CD-133 + cells compared to standard protocol of care alone (71). 
The transplantation of MSC showed therapeutic potential for liver function improvement according to recent experimental studies and human studies. Although they remain unclear, the major potential mechanisms have been proposed as a twofold; one is the improvement of the microenvironments through paracrine effects, and the other is the replacement of functional hepatocytes (76).

Dose response relationship has to be established in any drug product development. However, it is still unclear whether classical doseresponse exists with cell therapy. Review of cell therapy studies in heart disease has shown that the dose response was inconsistent and contradictory in terms of dose of administered cells and clinical response, both in preclinical and clinical setting (77). Most clinical trials apply MSCs according to the body weight of patients $(n=9,0.5-3 \times 10(6) / \mathrm{kg}$ as a single dose), while others apply MSCs according to the total quantity of cells $(n=7,1-20 \times 10(7))(78)$. In liver cirrhosis trial using bone marrow cells, Lyra et al noted that there was no correlation of number of cells and clinical improvement (79). However, in a dose ranging study using 5X10(5), $1 \times 10(6)$ and 2X10(6) cells/kg of CD34 + cells, Nakamura et al have observed improvement in patients who received middle or higher dose (59). It is important to accept that conclusion on dose response cannot be drawn from different trials. Among the recent clinical trials involving applying MSCs to treat liver diseases, the total number of MSCs used was from 10(7) - 10(9), regardless of which method was chosen to deliver MSCs (78).

There are few limitations for this study. First, we have not traced the cells within the body using radioactive technology owing to the inherent complexity of the procedure. Second, we do not have follow-up liver biopsy data. Third, the control group did not receive sham intervention or placebo injection due to ethical reasons. Fourth, the sample size was limited to 20 patients in each dose level, which is insufficient for meaningful detection of efficacy. Lastly, incorporation of a biomarker of liver regeneration like AFP would have provided insights into possible mechanism of action.

\section{Conclusion}

The present study has shown that it may be feasible and reasonably safe to administer stempeucel ${ }^{\circledR}$ through intraarterial route (hepatic artery) in ALC at a dose of up to 2.5 million cells/kg body weight. Higher doses of stempeucel ${ }^{\circledR}$ administered through the intraarterial (hepatic artery) route may not be justified in ALC owing to the limited efficacy seen at this dose and higher risk of complications at 5 million cells $/ \mathrm{kg}$ dose group. Efficacy was limited to improvement in quality of life in 2.5 million cells/kg dose group. Future studies have to be done to identify the appropriate dose and route of administering cell therapy for ALC.

\section{Abbreviations}

AFP: Alfa Fetoprotein

ALC: Alcoholic Liver Cirrhosis

BMMNCs: Bone marrow Mononuclear Cells

BMMSCs: Bone Marrow Mesenchymal Stromal Cells

CT: Computerized Tomography

DSMB: Data Safety Monitoring Board

G-CSF: Granulocyte-Colony Stimulating Factor (G-CSF)

HGF: Hepatocyte Growth Factor

IL: Interleukin

IMP: Investigational Medicinal Product

LFT: Liver Function Test

MELD: Model for End-Stage Liver Disease

MSCs: Mesenchymal Stromal Cells

SAE: Serious Adverse Events

SF-36: Short Form 36

Page $11 / 22$ 
SMA: Smooth Muscle Actin

SOC: System Organ Class

TEAEs: Treatment Emergent Adverse Events

TGF: Transforming Growth Factor

TNF: Tumor Necrosis Factor

UCMSCs: Umbilical Cord Mesenchymal Stem Cells

WCB: Working Bank Cell

\section{Declarations}

\section{Ethics approval and consent to participate}

The trial was conducted in accordance with the Declaration of Helsinki. The study was approved by institutional ethics committee and informed consent was taken from all individual participants.

\section{Consent for publication}

Written informed consent for publication of patient clinical details and/or clinical images was obtained from the patient/guardian of the patient. A copy of the consent form is available for review by the Editor of this journal

\section{Availability of data and materials}

The datasets used and/or analysed during the current study are available from the corresponding author on reasonable request.

\section{Competing interests}

The authors declare that they have no competing interests

\section{Funding}

Stempeutics Research Private Limited

\section{Authors' contributions}

I) Conception and design:

Dr. Pawan Kumar Gupta, Dr. Anoop Chullikana

(II) Administrative support:

Dr. Pawan Kumar Gupta, Dr. Anoop Chullikana, Dr. Raviraja NS, Dr. Udaykumar K, Dr. Shivashankar P, Mr. Pachaiyappan Viswanathan, Mr. Mithun Chandrashekar, Dr. Charan Thej, Mr. Prasanth KV, Mrs. Jijy Abraham, Dr. Anish Sen Majumdar

(III) Provision of study materials or patients:

Dr. Pawan Kumar Gupta, Dr. Anoop Chullikana, Dr. Charan Thej, Mr. Prasanth KV

(IV) Collection and assembly of data:

Dr. Pawan Kumar Gupta, Dr. Anoop Chullikana, Dr. Charan Thej, Mr. Prasanth KV, Mrs. Jijy Abraham, Dr. Anish Sen Majumdar

(V) Data analysis and interpretation:

Dr. Pawan Kumar Gupta, Dr. Anoop Chullikana, Dr. Anish Sen Majumdar

(VI) Manuscript writing: 
Dr. Pawan Kumar Gupta, Dr. Anoop Chullikana

(VII) Review of final manuscript:

All authors (Dr. Pawan Kumar Gupta, Dr. Anoop Chullikana, Dr. Raviraja NS, Dr. Udaykumar K, Dr. Shivashankar P, Mr. Pachaiyappan Viswanathan, Mr. Mithun Chandrashekar, Dr. Charan Thej, Mr. Prasanth KV, Mrs. Jijy Abraham, Dr. Anish Sen Majumdar)

(VII) Final approval of manuscript:

All authors (Dr. Pawan Kumar Gupta, Dr. Anoop Chullikana, Dr. Raviraja NS, Dr. Udaykumar K, Dr. Shivashankar P, Mr. Pachaiyappan Viswanathan, Mr. Mithun Chandrashekar, Dr. Charan Thej, Mr. Prasanth KV, Mrs. Jijy Abraham, Dr. Anish Sen Majumdar)

\section{Conflicts of Interest}

The authors have no conflicts of interest to declare

\section{References}

1. Bell H, Jahnsen J, Kittang E, Raknerud N, Sandvik L. Long-term prognosis of patients with alcoholic liver cirrhosis: A 15-year follow-up study of 100 Norwegian patients admitted to one unit. Scand J Gastroenterol [Internet]. 2004 Sep [cited 2020 Dec 18];39(9):858-63. Available from: https://pubmed.ncbi.nlm.nih.gov/15513384/

2. Pittenger MF, Mackay AM, Beck SC, Jaiswal RK, Douglas R, Mosca JD, et al. Multilineage potential of adult human mesenchymal stem cells. Science (80- ) [Internet]. 1999 Apr 2 [cited 2020 Dec 18];284(5411):143-7. Available from:

https://science.sciencemag.org/content/284/5411/143

3. Schwartz RE, Reyes M, Koodie L, Jiang Y, Blackstad M, Lund T, et al. Multipotent adult progenitor cells from bone marrow differentiate into functional hepatocyte-like cells. J Clin Invest [Internet]. 2002 May 15 [cited 2020 Dec 21];109(10):1291-302. Available from: https://pubmed.ncbi.nlm.nih.gov/12021244/

4. Jang YY, Collector MI, Baylin SB, Diehl AM, Sharkis SJ. Hematopoietic stem cells convert into liver cells within days without fusion. Nat Cell Biol [Internet]. 2004 Jun [cited 2020 Dec 21];6(6):532-9. Available from: https://pubmed.ncbi.nlm.nih.gov/15133469/

5. Banas A, Teratani T, Yamamoto Y, Tokuhara M, Takeshita F, Quinn G, et al. Adipose tissue-derived mesenchymal stem cells as a source of human hepatocytes. Hepatology [Internet]. 2007 Jul [cited 2020 Dec 21];46(1):219-28. Available from:

http://doi.wiley.com/10.1002/hep.21704

6. Aurich H, Sgodda M, Kaltwaßer P, Vetter M, Weise A, Liehr T, et al. Hepatocyte differentiation of mesenchymal stem cells from human adipose tissue in vitro promotes hepatic integration in vivo. Gut [Internet]. 2009 Apr 1 [cited 2020 Dec 21];58(4):570-81. Available from: https://gut.bmj.com/content/58/4/570

7. Stock P, Staege MS, Müller LP, Sgodda M, Völker A, Volkmer I, et al. Hepatocytes Derived From Adult Stem Cells. Transplant Proc. 2008 Mar 1;40(2):620-3.

8. Sato Y, Araki H, Kato J, Nakamura K, Kawano Y, Kobune M, et al. Human mesenchymal stem cells xenografted directly to rat liver are differentiated into human hepatocytes without fusion. Blood [Internet]. 2005 [cited 2020 Dec 21];106(2):756-63. Available from: http://ashpublications.org/blood/article-pdf/106/2/756/1711981/zh801405000756.pdf

9. Aurich I, Mueller LP, Aurich H, Luetzkendorf J, Tisljar K, Dollinger MM, et al. Functional integration of hepatocytes derived from human mesenchymal stem cells into mouse livers. Gut [Internet]. 2007 [cited 2020 Dec 21];56(3):405-15. Available from: www.gutjnl.com

10. Caplan Al, Dennis JE. Mesenchymal stem cells as trophic mediators [Internet]. Vol. 98, Journal of Cellular Biochemistry. John Wiley \& Sons, Ltd; 2006 [cited 2020 Dec 21]. p. 1076-84. Available from: http://doi.wiley.com/10.1002/jcb.20886

11. Parekkadan B, Van Poll D, Suganuma K, Carter EA, Berthiaume F, Tilles AW, et al. Mesenchymal stem cell-derived molecules reverse fulminant hepatic failure. PLoS One [Internet]. 2007 [cited 2020 Dec 21];2(9). Available from: www.plosone.org

12. Higashiyama R, Inagaki Y, Hong YY, Kushida M, Nakao S, Niioka M, et al. Bone marrow-derived cells express matrix metalloproteinases and contribute to regression of liver fibrosis in mice. Hepatology [Internet]. 2007 Jan [cited 2020 Dec 21];45(1):213-22. Available from: http://doi.wiley.com/10.1002/hep.21477

13. Zhao Z hai, Xin S jie, Zhao J min, Wang S shan, Liu P, Yin T yong, et al. Dynamic expression of matrix metalloproteinase-2, membrane type-matrix metalloproteinase-2 in experimental hepatic fibrosis and its reversal in rat. Zhonghua Shi Yan He Lin Chuang Bing Du Xue Za Zhi [Internet]. 2004 Dec 1 [cited 2020 Dec 21];18(4):328-31. Available from: http://europepmc.org/article/MED/15650781 
14. Parekkadan B, van Poll D, Megeed Z, Kobayashi N, Tilles AW, Berthiaume F, et al. Immunomodulation of activated hepatic stellate cells by mesenchymal stem cells. Biochem Biophys Res Commun. 2007;363(2):247-52.

15. Lin N, Hu K, Chen S, Xie S, Tang Z, Lin J, et al. Nerve growth factor-mediated paracrine regulation of hepatic stellate cells by multipotent mesenchymal stromal cells. Life Sci. 2009 Aug 12;85(7-8):291-5.

16. Wang $X$, Willenbring $H$, Akkari $Y$, Torimaru $Y$, Foster $M$, Al-Dhalimy $M$, et al. Cell fusion is the principal source of bone-marrow-derived hepatocytes. Nature [Internet]. 2003 Apr 24 [cited 2020 Dec 21];422(6934):897-901. Available from: https://pubmed.ncbi.nlm.nih.gov/12665832/

17. Vassilopoulos G, Wang PR, Russell DW. Transplanted bone marrow regenerates liver by cell fusion. Nature. 2003 Apr 24;422(6934):901-4.

18. Jin G, Qiu G, Wu D, Hu Y, Qiao P, Fan C, et al. Allogeneic bone marrow-derived mesenchymal stem cells attenuate hepatic ischemiareperfusion injury by suppressing oxidative stress and inhibiting apoptosis in rats. Int J Mol Med [Internet]. 2013 Jun 1 [cited 2020 Dec 21];31(6):1395-401. Available from: http://www.spandidos-publications.com/10.3892/ijmm.2013.1340/abstract

19. Tang J, Xie Q, Pan G, Wang J, Wang M. Mesenchymal stem cells participate in angiogenesis and improve heart function in rat model of myocardial ischemia with reperfusion. Eur J Cardio-thoracic Surg [Internet]. 2006 [cited 2020 Dec 21];30(2):353-61. Available from: www.elsevier.com/locate/ejcts

20. Zhang GZ, Sun HC, Zheng LB, Guo JB, Zhang XL. In vivo hepatic differentiation potential of human umbilical cord-derived mesenchymal stem cells: Therapeutic effect on liver fibrosis/cirrhosis. World J Gastroenterol [Internet]. 2017 Dec 14 [cited 2020 Dec 18];23(46):8152-68. Available from: https://pubmed.ncbi.nlm.nih.gov/29290652/

21. Chang YJ, Liu JW, Lin PC, Sun LY, Peng CW, Luo GH, et al. Mesenchymal stem cells facilitate recovery from chemically induced liver damage and decrease liver fibrosis. Life Sci [Internet]. 2009 Sep 23 [cited 2020 Dec 21];85(13-14):517-25. Available from: https://pubmed.ncbi.nlm.nih.gov/19686763/

22. Tanimoto H, Terai S, Taro T, Murata Y, Fujisawa K, Yamamoto N, et al. Improvement of liver fibrosis by infusion of cultured cells derived from human bone marrow. Cell Tissue Res [Internet]. 2013 Dec [cited 2020 Dec 21];354(3):717-28. Available from: https://pubmed.ncbi.nlm.nih.gov/24104560/

23. Jang YO, Kim YJ, Baik SK, Kim MY, Eom YW, Cho MY, et al. Histological improvement following administration of autologous bone marrow-derived mesenchymal stem cells for alcoholic cirrhosis: A pilot study. Liver Int [Internet]. 2014 Jan 1 [cited 2020 Dec 21];34(1):33-41. Available from: http://doi.wiley.com/10.1111/liv.12218

24. El-Ansary M, Abdel-Aziz I, Mogawer S, Abd Elhamid SM, Hammam O, Teaema S, et al. Phase II Trial: Undifferentiated Versus Differentiated Autologous Mesenchymal Stem Cells Transplantation in Egyptian Patients with HCV Induced Liver Cirrhosis. Stem Cell Rev Reports [Internet]. 2012 Jan 1 [cited 2020 Dec 21];8(3):972-81. Available from: https://pubmed.ncbi.nlm.nih.gov/21989829/

25. Amin MA, Sabry D, Rashed LA, Aref WM, El-Ghobary MA, Farhan MS, et al. Short-term evaluation of autologous transplantation of bone marrow-derived mesenchymal stem cells in patients with cirrhosis: Egyptian study. Clin Transplant [Internet]. 2013 Jul 1 [cited 2020 Dec 21];27(4):607-12. Available from: http://doi.wiley.com/10.1111/ctr.12179

26. Peng L, Xie D ying, Lin BL, Liu J, Zhu H peng, Xie C, et al. Autologous bone marrow mesenchymal stem cell transplantation in liver failure patients caused by hepatitis B: Short-term and long-term outcomes. Hepatology [Internet]. 2011 Sep 2 [cited 2020 Dec 21];54(3):820-8. Available from: http://doi.wiley.com/10.1002/hep.24434

27. Zhang Z, Lin H, Shi M, Xu R, Fu J, Lv J, et al. Human umbilical cord mesenchymal stem cells improve liver function and ascites in decompensated liver cirrhosis patients. J Gastroenterol Hepatol [Internet]. 2012 [cited 2020 Dec 21];27(SUPPL.2):112-20. Available from: https://onlinelibrary.wiley.com/doi/full/10.1111/j.1440-1746.2011.07024.x

28. Shi M, Zhang Z, Xu R, Lin H, Fu J, Zou Z, et al. Human Mesenchymal Stem Cell Transfusion Is Safe and Improves Liver Function in Acute-on-Chronic Liver Failure Patients. Stem Cells Transl Med [Internet]. 2012 Oct 1 [cited 2020 Dec 21];1(10):725-31. Available from: http://doi.wiley.com/10.5966/sctm.2012-0034

29. Pal R, Hanwate M, Totey SM. Effect of holding time, temperature and different parenteral solutions on viability and functionality of adult bone marrow-derived mesenchymal stem cells before transplantation. J Tissue Eng Regen Med [Internet]. 2008 Oct 1 [cited 2020 Dec 21];2(7):436-44. Available from: http://doi.wiley.com/10.1002/term.109

30. Gupta PK, Chullikana A, Parakh R, Desai S, Das A, Gottipamula S, et al. A double blind randomized placebo controlled phase I/II study assessing the safety and efficacy of allogeneic bone marrow derived mesenchymal stem cell in critical limb ischemia. $\mathrm{J}$ Transl Med [Internet]. 2013 [cited 2020 Dec 21];11(1):1. Available from: http://www.clinicaltrials.gov/ct2/show/NCT00883870

31. Seldinger SI. Catheter replacement of the needle in percutaneous arteriography: A new technique. Acta radiol [Internet]. 1953 May 1 [cited 2020 Dec 21];39(5):368-76. Available from: https://pubmed.ncbi.nlm.nih.gov/13057644/

Page $14 / 22$ 
32. Reed ML, Kuipers FM, Vaitkevicius VK, Clark MD, Drake EH, Eyler WR. Treatment of Disseminated Carcinoid Tumors Including HepaticArtery Catheterization. N Engl J Med [Internet]. 1963 Nov 7 [cited 2020 Dec 21];269(19):1005-10. Available from: https://www.nejm.org/doi/10.1056/NEJM196311072691904

33. KHAZEI AM, WATKINS E, SULLIVAN RD. HEPATIC ARTERY CATHETERIZATION FOR PROLONGED INFUSION CHEMOTHERAPY OF LIVER CANCER. Surg Clin North Am. 1964 Jun 1;44(3):763-78.

34. Habbe TG, McCowan TC, Goertzen TC, Leveen RF, Culp WC, Tempero MA. Complications and technical limitations of hepatic arterial infusion catheter placement for chemotherapy. J Vasc Interv Radiol [Internet]. 1998 [cited 2020 Dec 21];9(2):233-9. Available from: https://pubmed.ncbi.nlm.nih.gov/9540905/

35. Pingpank JF, Libutti SK, Chang R, Wood BJ, Neeman Z, Kam AW, et al. Phase I study of hepatic arterial melphalan infusion and hepatic venous hemofiltration using percutaneously placed catheters in patients with unresectable hepatic malignancies. J Clin Oncol. 2005;23(15):3465-74.

36. Herrmann KA, Waggershauser T, Sittek H, Reiser MF. Liver intraarterial chemotherapy: Use of the femoral artery for percutaneous implantation of catheter-port systems. Radiology [Internet]. 2000 [cited 2020 Dec 21];215(1):294-9. Available from: https://pubmed.ncbi.nlm.nih.gov/10751501/

37. Couto BG, Goldenberg RC do. S, Da Fonseca LMB, Thomas J, Gutfilen B, Resende CMC, et al. Bone marrow mononuclear cell therapy for patients with cirrhosis: A Phase 1 study. Liver Int. 2011 Mar;31(3):391-400.

38. Sharma M, Rao PN, Sasikala M, Kuncharam MR, Reddy C, Gokak V, et al. Autologous mobilized peripheral blood CD34+ cell infusion in non-viral decompensated liver cirrhosis. World J Gastroenterol [Internet]. 2015 [cited 2020 Dec 21];21(23):7264-71. Available from: http://www.wjgnet.com/esps/HelpDesk:http://www.wjgnet.com/esps/helpdesk.aspx

39. Gasbarrini A, Rapaccini GL, Rutella S, Zocco MA, Tittoto P, Leone G, et al. Rescue therapy by portal infusion of autologous stem cells in a case of drug-induced hepatitis. Dig Liver Dis [Internet]. 2007 Sep 1 [cited 2020 Dec 21];39(9):878-82. Available from: http://www.dldjournalonline.com/article/S1590865806003124/fulltext

40. Terai S, Ishikawa T, Omori K, Aoyama K, Marumoto Y, Urata Y, et al. Improved Liver Function in Patients with Liver Cirrhosis After Autologous Bone Marrow Cell Infusion Therapy. Stem Cells [Internet]. 2006 Oct 1 [cited 2020 Dec 21];24(10):2292-8. Available from: http://doi.wiley.com/10.1634/stemcells.2005-0542

41. Reinders MEJ, de Fijter JW, Roelofs H, Bajema IM, de Vries DK, Schaapherder AF, et al. Autologous Bone Marrow-Derived Mesenchymal Stromal Cells for the Treatment of Allograft Rejection After Renal Transplantation: Results of a Phase I Study. Stem Cells Transl Med [Internet]. 2013 [cited 2020 Dec 21];2(2):107-11. Available from: http://dx.doi.org/10.5966/sctm.2012-0114

42. Bank JR, Rabelink TJ, De Fijter JW, Reinders MEJ. Safety and Efficacy Endpoints for Mesenchymal Stromal Cell Therapy in Renal Transplant Recipients. J Immunol Res [Internet]. 2015 [cited 2020 Dec 21];2015:1-14. Available from: http://dx.doi.org/10.1155/2015/391797

43. von Bahr L, Sundberg B, Lönnies L, Sander B, Karbach H, Hägglund H, et al. Long-term complications, immunologic effects, and role of passage for outcome in mesenchymal stromal cell therapy. Biol Blood Marrow Transplant [Internet]. 2012 [cited 2020 Dec 21];18(4):557-64. Available from: https://reader.elsevier.com/reader/sd/pii/S1083879111003235? token=80CC24B43E031D85A45B474B11AC0DC4AFDF498CB8BFA9F705C24D056114B30CEAF5CB03A64D709DBD8853BDF1675E0F

44. Lalu MM, Mclntyre L, Pugliese C, Fergusson D, Winston BW, Marshall JC, et al. Safety of Cell Therapy with Mesenchymal Stromal Cells (SafeCell): A Systematic Review and Meta-Analysis of Clinical Trials [Internet]. Vol. 7, PLoS ONE. 2012 [cited 2020 Dec 21 ]. p. 1-21. Available from: www.plosone.org

45. Auletta JJ, Deans RJ, Bartholomew AM. Emerging roles for multipotent, bone marrow-derived stromal cells in host defense [Internet]. Vol. 119, Blood. 2012 [cited 2020 Dec 21]. p. 1801-9. Available from: www.bloodjournal.org

46. Meisel R, Brockers S, Heseler K, Degistirici O, Bülle H, Woite C, et al. Human but not murine multipotent mesenchymal stromal cells exhibit broad-spectrum antimicrobial effector function mediated by indoleamine 2,3-dioxygenase. Leuk Off J Leuk Soc Am Leuk Res Fund, UK [Internet]. 2011 [cited 2020 Dec 22];25(4):648-54. Available from: www.nature.com/leu

47. Krasnodembskaya A, Song Y, Fang X, Gupta N, Serikov V, Lee JW, et al. Antibacterial effect of human mesenchymal stem cells is mediated in part from secretion of the antimicrobial peptide LL-37. Stem Cells. 2010;28(12):2229-38.

48. Yang R, Liu Y, Kelk P, Qu C, Akiyama K, Chen C, et al. A subset of IL-17 + mesenchymal stem cells possesses anti-Candida albicans effect. Cell Res [Internet]. 2013 [cited 2020 Dec 22];23(1):107-21. Available from: www.cell-research.com

49. Eswara Prasad RNI. Role of Mesenchymal Stem Cell Based Therapies in MDR/ XDR TB and Co-Morbidities. J Stem Cell Res Ther. 2015;05(05):284. 
50. Kusadasi N, Groeneveld ABJ. A perspective on mesenchymal stromal cell transplantation in the treatment of sepsis [Internet]. Vol. 40, Shock. 2013 [cited 2020 Dec 22]. p. 352-7. Available from: http://journals.Iww.com/00024382-201311000-00002

51. Lee JW, Krasnodembskaya A, McKenna DH, Song Y, Abbott J, Matthay MA. Therapeutic effects of human mesenchymal stem cells in ex vivo human lungs injured with live bacteria. Am J Respir Crit Care Med [Internet]. 2013 [cited 2020 Dec 22];187(7):751-60. Available from: www.atsjournals.org

52. Shin S, Kim Y, Jeong S, Hong S, Kim I, Lee W, et al. The therapeutic effect of human adult stem cells derived from adipose tissue in endotoxemic rat model. Int J Med Sci [Internet]. 2012 [cited 2020 Dec 22];10(1):8-18. Available from: http://www.medsci.org8

53. Mclntyre LA, Stewart DJ, Mei SHJ, Courtman D, Watpool I, Granton J, et al. Cellular immunotherapy for septic shock: A phase I clinical trial. Am J Respir Crit Care Med. 2018 Feb 1;197(3):337-47.

54. Arango-Rodriguez ML. Could cancer and infection be adverse effects of mesenchymal stromal cell therapy? World J Stem Cells [Internet]. 2015 [cited 2020 Dec 22];7(2):408. Available from: https://pubmed.ncbi.nlm.nih.gov/25815124/

55. Amer MEM, El-Sayed SZ, El-Kheir WA, Gabr H, Gomaa AA, El-Noomani N, et al. Clinical and laboratory evaluation of patients with endstage liver cell failure injected with bone marrow-derived hepatocyte-like cells. Eur J Gastroenterol Hepatol [Internet]. 2011 Oct [cited 2020 Dec 22];23(10):936-41. Available from: https://pubmed.ncbi.nIm.nih.gov/21900788/

56. Mohamadnejad M, Alimoghaddam K, Mohyeddin-Bonab M, Bagheri M, Bashtar M, Ghanaati H, et al. Phase 1 trial of autologous bone marrow mesenchymal stem cell transplantation in patients with decompensated liver cirrhosis. Arch Iran Med [Internet]. 2007 [cited 2020 Dec 22];10(4):459-66. Available from: www.wjgnet.com

57. Pai M, Zacharoulis D, Milicevic MN, Helmy S, Jiao LR, Levičar N, et al. Autologous infusion of expanded mobilized adult bone marrowderived CD34+ cells into patients with alcoholic liver cirrhosis. Am J Gastroenterol [Internet]. 2008 Aug [cited 2020 Dec 22];103(8):1952-8. Available from: https://pubmed.ncbi.nlm.nih.gov/18637092/

58. Khan AA, Parveen N, Mahaboob VS, Rajendraprasad A, Ravindraprakash HR, Venkateswarlu J, et al. Safety and Efficacy of Autologous Bone Marrow Stem Cell Transplantation Through Hepatic Artery for the Treatment of Chronic Liver Failure: A Preliminary Study. Transplant Proc [Internet]. 2008 May [cited 2020 Dec 22];40(4):1140-4. Available from: https://pubmed.ncbi.nlm.nih.gov/18555134/

59. Nakamura T, Torimura T, Iwamoto H, Kurogi J, Inoue H, Hori Y, et al. CD34+ cell therapy is safe and effective in slowing the decline of hepatic reserve function in patients with decompensated liver cirrhosis. J Gastroenterol Hepatol [Internet]. 2014 Oct 1 [cited 2020 Dec 22];29(10):1830-8. Available from: http://doi.wiley.com/10.1111/jgh.12622

60. Salama H, Zekri ARN, Ahmed R, Medhat I, Abdallah ES, Darwish T, et al. Assessment of health-related quality of life in patients receiving stem cell therapy for end-stage liver disease: An Egyptian study. Stem Cell Res Ther [Internet]. 2012 Dec 3 [cited 2020 Dec 22];3(6):49. Available from: http://stemcellres.com/content/3/6/49

61. Kim JK, Park YN, Kim JS, Park MS, Paik YH, Seok JY, et al. Autologous bone marrow infusion activates the progenitor cell compartment in patients with advanced liver cirrhosis. Cell Transplant [Internet]. 2010 [cited 2020 Dec 22];19(10):1237-46. Available from: www.cognizantcommunication.com

62. Mohamadnejad M, Alimoghaddam K, Bagheri M, Ashrafi M, Abdollahzadeh L, Akhlaghpoor S, et al. Randomized placebo-controlled trial of mesenchymal stem cell transplantation in decompensated cirrhosis. Liver Int [Internet]. 2013 Nov [cited 2020 Dec 22];33(10):14906. Available from: https://pubmed.ncbi.nlm.nih.gov/23763455/

63. Mohamadnejad M, Vosough M, Moossavi S, Nikfam S, Mardpour S, Akhlaghpoor S, et al. Intraportal Infusion of Bone Marrow Mononuclear or CD133 + Cells in Patients With Decompensated Cirrhosis: A Double-Blind Randomized Controlled Trial. Stem Cells Transl Med [Internet]. 2016 [cited 2020 Dec 22];5(1):87-94. Available from: http://www.bd.com

64. Tucker JD, Ericksen JJ, Goetz LL, Elmore LW. Should clinical studies involving "regenerative injection therapy," strive to incorporate a triad of outcome measures instead of only including clinical outcome measures? [Internet]. Vol. 22, Osteoarthritis and Cartilage. W.B. Saunders Ltd; 2014 [cited 2020 Dec 22]. p. 715-7. Available from: https://pubmed.ncbi.nlm.nih.gov/24769241/

65. Yannaki E, Anagnostopoulos A, Kapetanos D, Xagorari A, lordanidis F, Batsis I, et al. Lasting amelioration in the clinical course of decompensated alcoholic cirrhosis with boost infusions of mobilized peripheral blood stem cells. Exp Hematol [Internet]. 2006 Nov [cited 2020 Dec 22];34(11):1583-7. Available from: https://pubmed.ncbi.nlm.nih.gov/17046578/

66. Maharaj B, Leary WP, Naran AD, Maharaj RJ, Cooppan RM, Pirie D, et al. SAMPLING VARIABILITY AND ITS INFLUENCE ON THE DIAGNOSTIC YIELD OF PERCUTANEOUS NEEDLE BIOPSY OF THE LIVER. Lancet [Internet]. 1986 Mar 8 [cited 2020 Dec 22];327(8480):523-5. Available from: http://www.thelancet.com/article/S0140673686908834/fulltext

67. Regev A, Berho M, Jeffers LJ, Milikowski C, Molina EG, Pyrsopoulos NT, et al. Sampling error and intraobserver variation in liver biopsy in patients with chronic HCV infection. Am J Gastroenterol [Internet]. 2002 Oct [cited 2020 Dec 22];97(10):2614-8. Available from: https://pubmed.ncbi.nlm.nih.gov/12385448/ 
68. Foucher J, Chanteloup E, Vergniol J, Castéra L, Le Bail B, Adhoute X, et al. Diagnosis of cirrhosis by transient elastography (FibroScan): A prospective study. Gut [Internet]. 2006 [cited 2020 Dec 22];55(3):403-8. Available from: www.gutjnl.com

69. Castera L, Forns X, Alberti A. Non-invasive evaluation of liver fibrosis using transient elastography. J Hepatol [Internet]. 2008 May [cited 2020 Dec 22];48(5):835-47. Available from: https://pubmed.ncbi.nlm.nih.gov/18334275/

70. Malekzadeh R, Poustchi H. Fibroscan for assessing liver fibrosis: An acceptable alternative for liver biopsy [Internet]. Vol. 11, Hepatitis Monthly. Kowsar Medical Institute; 2011 [cited 2020 Dec 22]. Available from: www.HepatMon.ir

71. King A, Barton D, Beard HA, Than N, Moore J, Corbett C, et al. REpeated AutoLogous Infusions of STem cells in Cirrhosis (REALISTIC): A multicentre, phase II, open-label, randomised controlled trial of repeated autologous infusions of granulocyte colony-stimulating factor (GCSF) mobilised CD133+ bone marrow stem cells. BMJ Open [Internet]. 2015 [cited 2020 Dec 22];5(3). Available from: http://bmjopen.bmj.com/

72. Mohsin S, Shams S, Ali Nasir G, Khan M, Javaid Awan S, Khan SN, et al. Enhanced hepatic differentiation of mesenchymal stem cells after pretreatment with injured liver tissue. Differentiation [Internet]. 2011 Jan [cited 2020 Dec 22];81(1):42-8. Available from: https://pubmed.ncbi.nlm.nih.gov/20943307/

73. Salama H, Zekri ARN, Medhat E, Al Alim SA, Ahmed OS, Bahnassy AA, et al. Peripheral vein infusion of autologous mesenchymal stem cells in Egyptian HCV-positive patients with end-stage liver disease. Stem Cell Res Ther [Internet]. 2014 [cited 2020 Dec 22];5(3):1-12. Available from: http://stemcellres.com/content/5/3/70

74. Vosough M, Moossavi S, Mardpour S, Akhlaghpoor S, Azimian V, Jarughi N, et al. Repeated intraportal injection of mesenchymal stem cells in combination with pioglitazone in patients with compensated cirrhosis: A clinical report of two cases. Arch Iran Med [Internet]. 2016 [cited 2020 Dec 22];19(2):131-6. Available from: https://pubmed.ncbi.nlm.nih.gov/26838084/

75. Zekri ARN, Salama H, Medhat E, Musa S, Abdel-Haleem H, Ahmed OS, et al. The impact of repeated autologous infusion of haematopoietic stem cells in patients with liver insufficiency. Stem Cell Res Ther [Internet]. 2015 Jun 11 [cited 2020 Dec 22];6(1):118. Available from: http://stemcellres.com/content/6/1/118

76. Zhang Z, Wang FS. Stem cell therapies for liver failure and cirrhosis. Vol. 59, Journal of Hepatology. Elsevier B.V.; 2013. p. 183-5.

77. Golpanian S, Schulman IH, Ebert RF, Heldman AW, DiFede DL, Yang PC, et al. Concise Review: Review and Perspective of Cell Dosage and Routes of Administration From Preclinical and Clinical Studies of Stem Cell Therapy for Heart Disease. Stem Cells Transl Med [Internet]. 2016 Feb [cited 2020 Dec 22];5(2):186-91. Available from: https://pubmed.ncbi.nlm.nih.gov/26683870/

78. Yang X, Meng Y, Han Z, Ye F, Wei L, Zong C. Mesenchymal stem cell therapy for liver disease: full of chances and challenges. Cell Biosci [Internet]. 2020 Dec 1 [cited 2020 Dec 22];10(1):123. Available from: https://doi.org/10.1186/s13578-020-00480-6

79. Lyra AC, Soares MBP, Da Silva LFM, Braga EL, Oliveira SA, Fortes MF, et al. Infusion of autologous bone marrow mononuclear cells through hepatic artery results in a short-term improvement of liver function in patients with chronic liver disease: A pilot randomized controlled study. Eur J Gastroenterol Hepatol [Internet]. 2010 Jan [cited 2020 Dec 22];22(1):33-42. Available from: https://pubmed.ncbi.nlm.nih.gov/19654548/

\section{Figures}




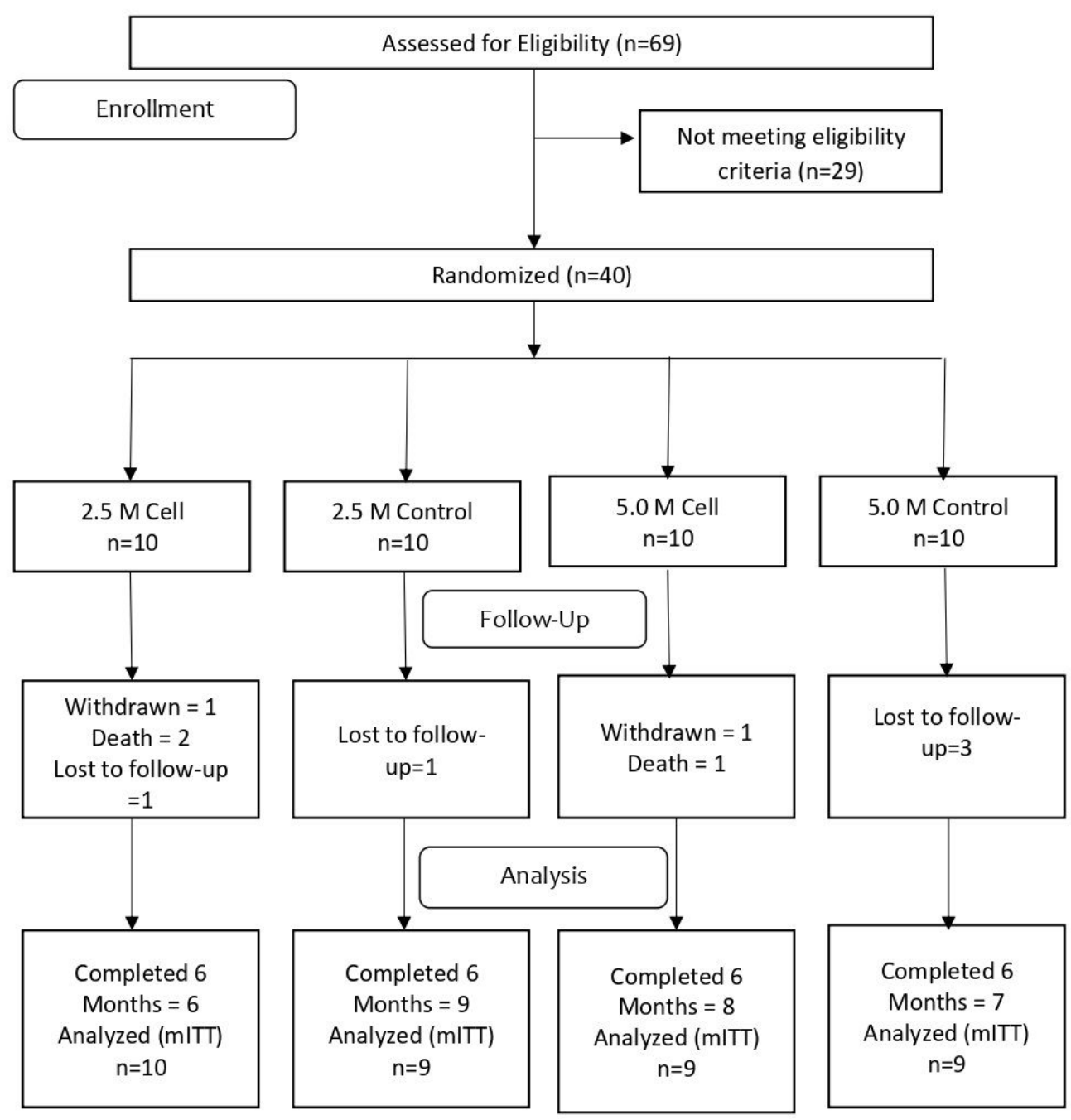

Figure 1

CONSORT diagram showing number of patients randomized to each group, followed up and analyzed 


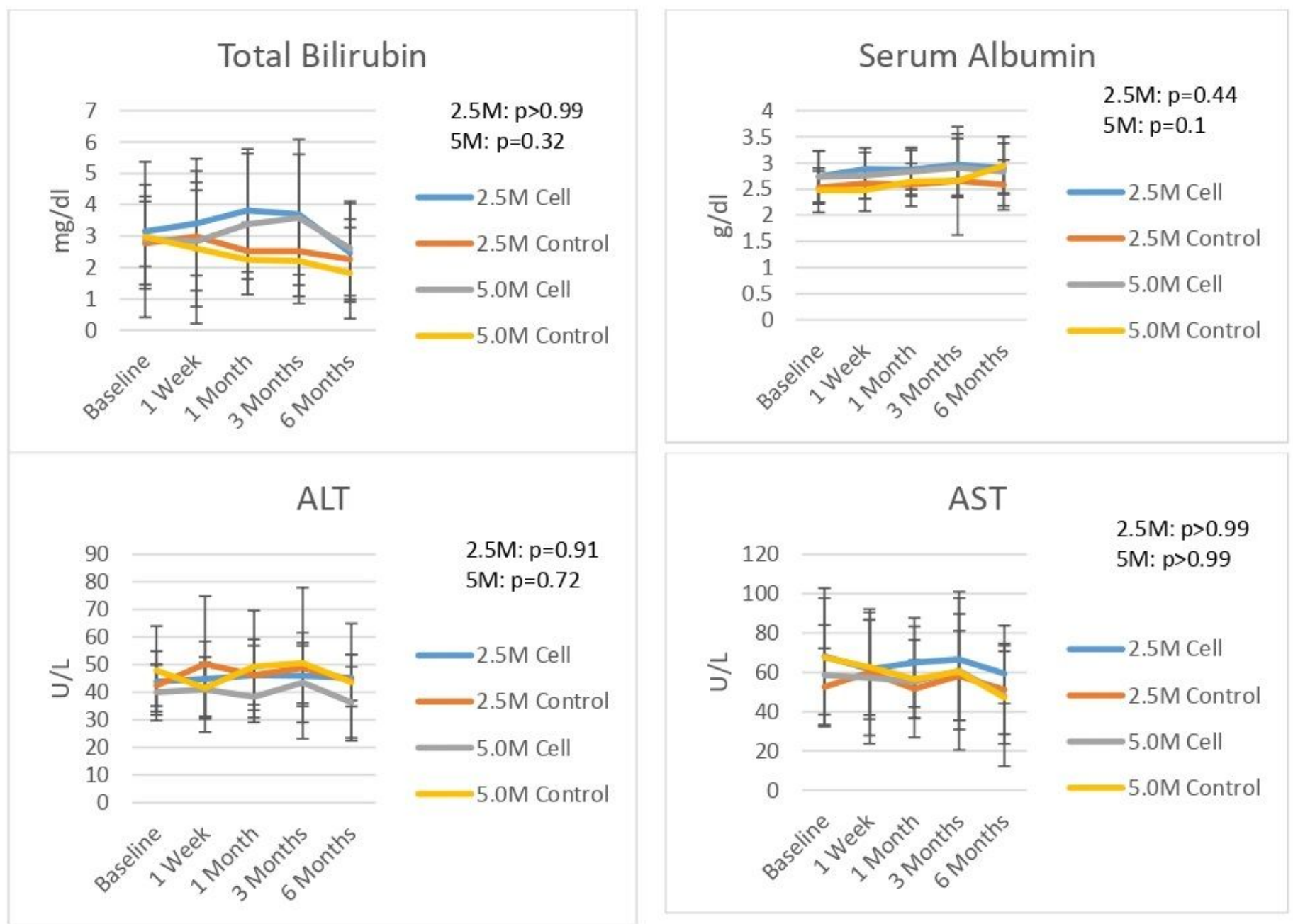

\section{Figure 2}

Liver function test in different visits: a. Total bilirubin, b. Serum albumin, c. Alanine aminotransferase (ALT), d. Aspartate aminotransferase (AST)
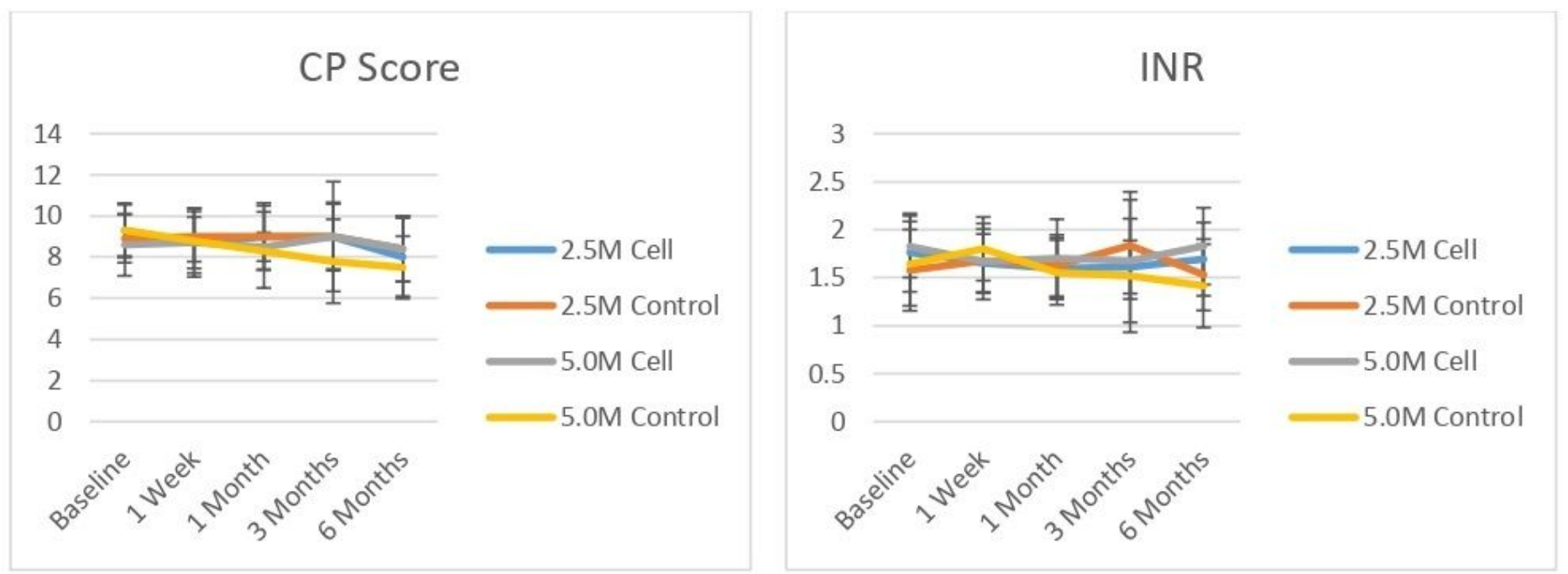

Figure 3 
Child Pugh Score (a) and INR (b) in different visits
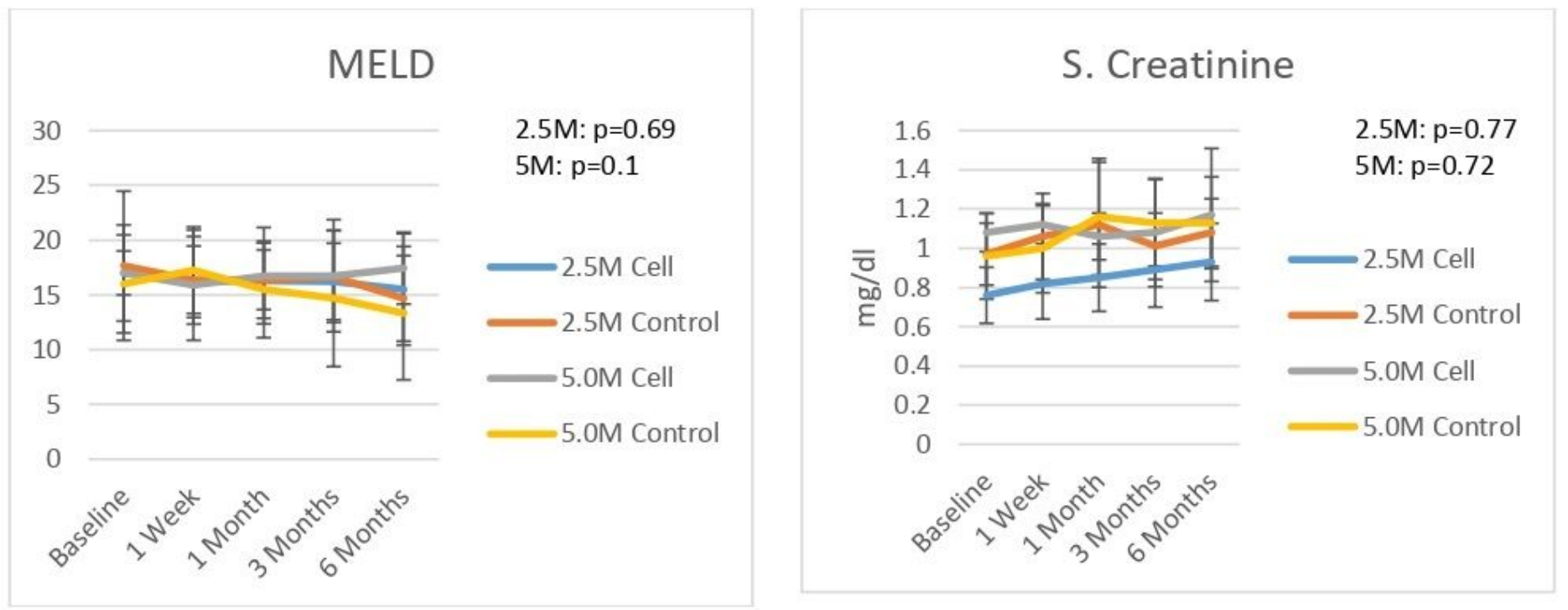

\section{Figure 4}

MELD score (a) and serum creatinine (b) in different visits 


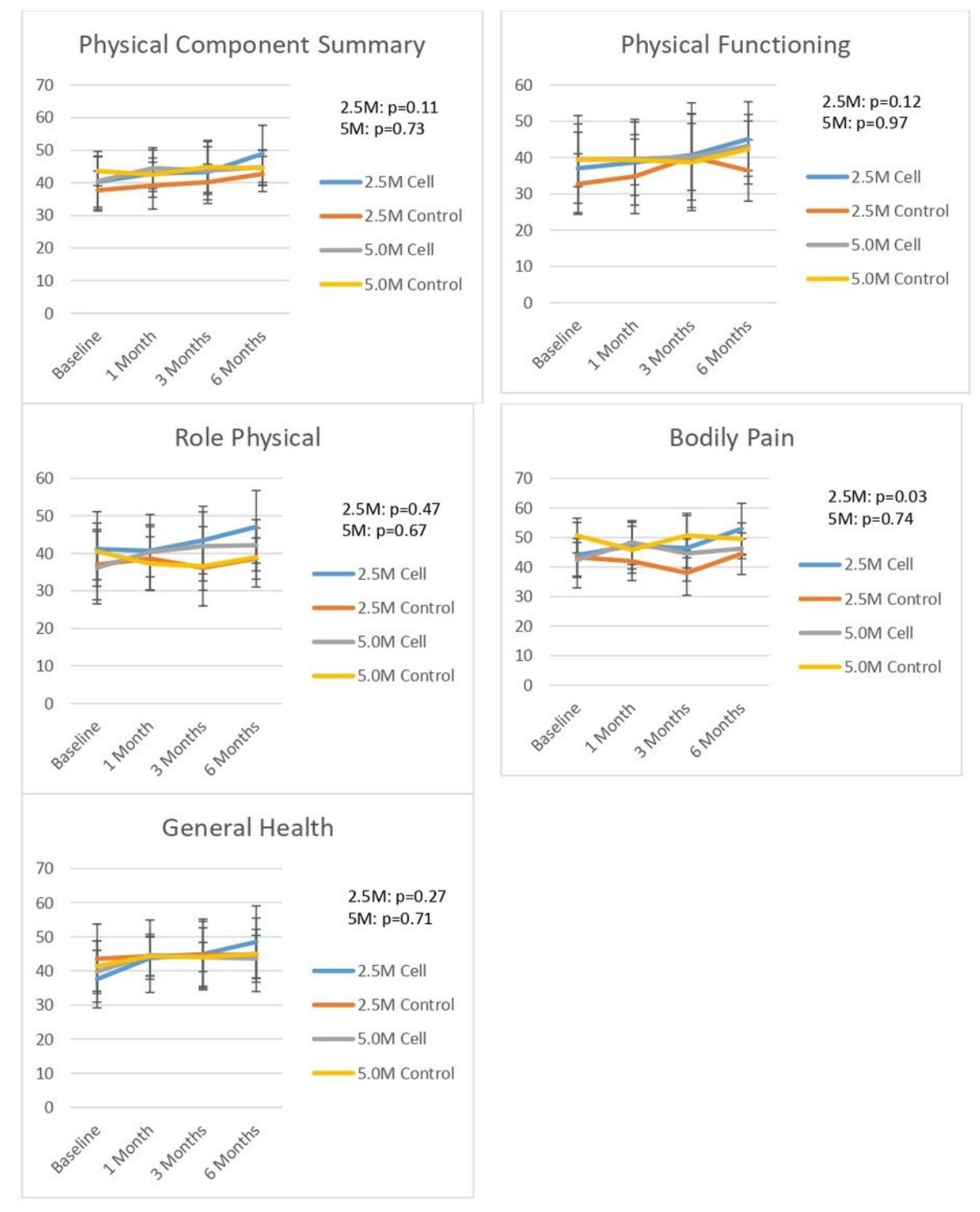

Figure 5

SF 36 Physical component Scores: a. Physical Component Summary, b. Physical Functioning, c. Role Physical, d. Bodily Pain, e. General Health 


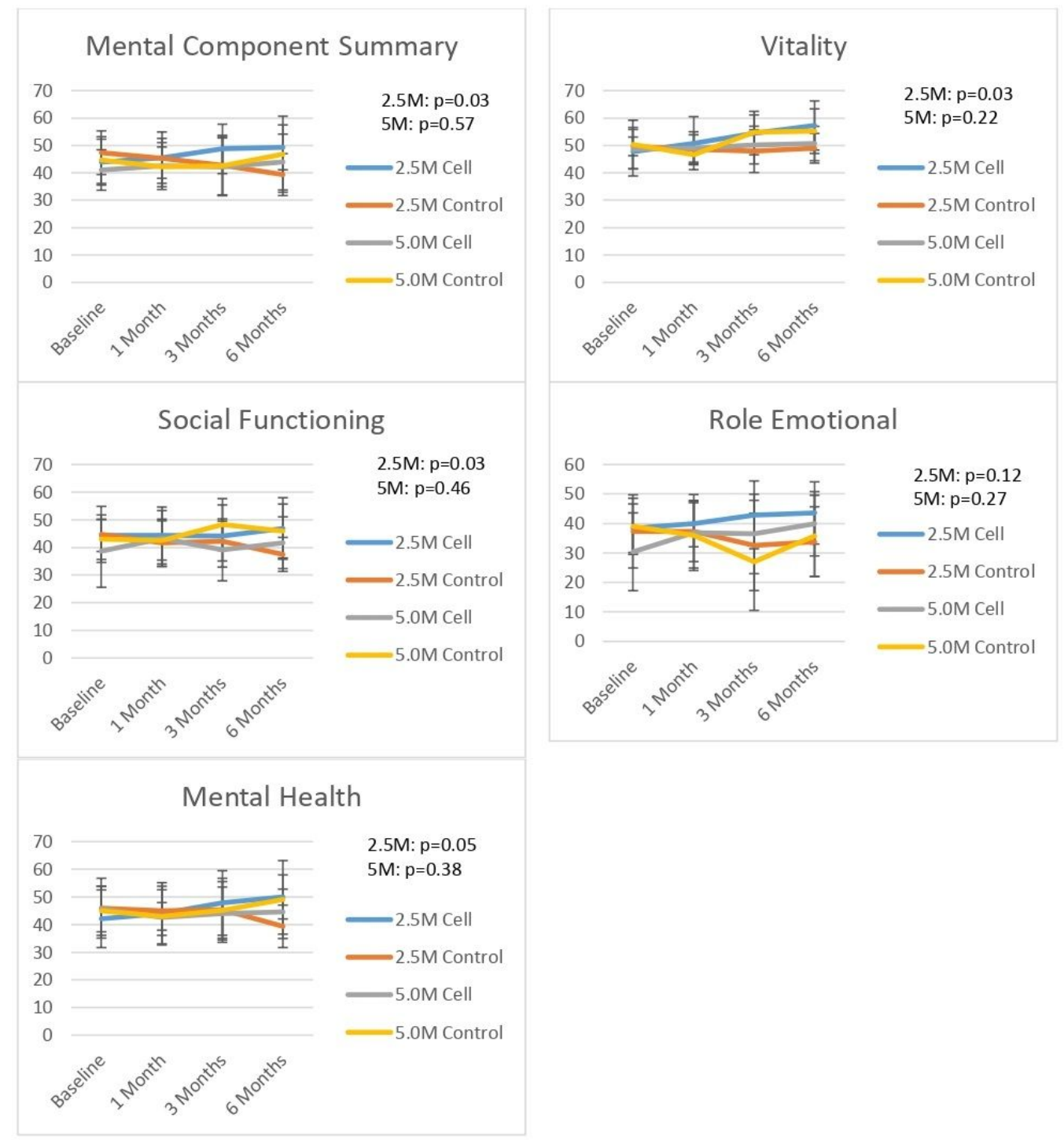

Figure 6

SF 36 Mental Component Scores: a. Mental Component Summary, b. Vitality, c. Social Functioning, d. Role Emotional, e. Mental Health 